\title{
Entomofauna of Oil Palm Tree Inflorescences at La Mé Experimental Station (Côte d'Ivoire)
}

\author{
N. Hala ${ }^{1}$, Y. Tuo ${ }^{2}$, A. A. M. Akpesse ${ }^{2}$, H. K. Koua ${ }^{2}$ and Y. Tano ${ }^{2}$ \\ ${ }^{1}$ National Center of Agronomic Research (CNRA) - 01 BP 1740 Abidjan 01, Côte d'Ivoire. \\ ${ }^{2}$ UFR Biosciences, Laboratory of Zoology and Animal Biology; 22 BP: 587 Abidjan 22,
} Côte d'Ivoire.

Research Article

Received $2^{\text {nd }}$ February 2012

Accepted $29^{\text {th }}$ March 2012

Online Ready $12^{\text {th }}$ April 2012

\section{ABSTRACT}

Pollination of oil palm tree is mainly entomophilous. The inflorescences of this plant lodge many insects. The identification and quantification of these insects have proven ability to hold their pollination. The entomofauna of female and male inflorescences was inventoried and quantified at La Mé, a station of CNRA, the National Center of Agronomic Research of Côte d'Ivoire (West Africa) for a period of 2 years. The insects of the male inflorescences were listed at the beginning, the full and the end of anthesis on 1536 spikelets of 384 male inflorescences. For the insects of female inflorescences, 96 inflorescences were covered with a muslin sheath. The insects arriving on these inflorescences were captured in 2 days corresponding to anthesis length, during 10 minutes per hour, from 6 am to $6 \mathrm{pm}$. Species Elaeidobius sp., Microporum sp., Prosoestus sp. and Atheta burgeoni were common and regular present regardless of inflorescence type. Species Gabrius sp., Thrips sp., Anthocoride sp., Lithargus sp. and the bees (Nomia sp. and Apis mellifera) were rarely observed in female inflorescences. Elaeidobius kamerunicus and Prosoestus sp. were more abundant on the female than on the male inflorescences. The higher level of insects was observed in full anthesis on male inflorescences whereas among female inflorescences it was noted at the first day of flowering. Knowledge of the insect fauna of oil palm inflorescences according to different stages of flowering allows better management of pollination.

Keywords: Entomofauna; oil palm; inflorescences; La Mé; Côte d'Ivoire.

*Corresponding author: Email: hervkoua@yahoo.fr; 


\section{INTRODUCTION}

The world production of oil palm was 38 million tons in 2007. Since this year, oil palm was the first oleaginous plant before soya and colza (Boutin, 2007). Côte d'lvoire (West Africa) produced 300000 tons of palm oil and appears to be the only one able to provide UEMOA (West African Economic and Monetary Union) market with this product. This country intends to double the current production before 2020 to solve its own food and industrial needs which increase ceaselessly and to fill UEMOA market deficit (Anonyme, 2009). Oil palm tree pollination is essentially entomophilous and constitutes an important factor to reach this objective. The works of Chevalier (1910), Syed (1979) and Syed et al. (1982) had clarified the role of insects, particularly those of the Elaeidobius genus in the pollination of oil palm tree. Unfortunately, these insects are rarely taken into account in oil palm improvement programs in Africa. Oil palm production structures in Côte d'Ivoire based their activities on soil fertility, research of resistant and productive plant material and on pests' control. Phytosanitary services only control the levels of pest. Natural pollination by the insects constitutes the only alternative for the African producers who can't afford another solution. The last control of oil palm tree pollinating insects was done since 1992 by the National Center of Agronomic Research (CNRA). The results of this monitoring showed that the insects of male and female inflorescences of oil palm tree, taken randomly from 50 male inflorescences and 48 female inflorescences had yielded 16 insect species for males and 10 species in female inflorescences. Knowledge of the levels of population of these pollinating insects in time as well as the factors which can influence their activities is essential. This preliminary study aims to present oil palm tree inflorescences entomofauna, 17 years after the last control set up in La Mé (Côte d'Ivoire), one of the most important experimental research stations of this crop.

\section{MATERIALS AND METHODS}

\subsection{Study Site}

This work was carried out at La Mé station $\left(5^{\circ} 26^{\prime} \mathrm{N}, 3^{\circ} 50^{\prime} \mathrm{W}\right)$. The station is in the ombrophilous forest, far approximately $30 \mathrm{~km}$ in the northeast of Abidjan the economic capital of Côte d'Ivoire (Traoré and Mangara, 2009). It is located in tropical rainforest climate, also known as equatorial climate (Pene and Assa, 2003); characterized by two distinct rainy seasons (March to July and November) alternating with two dry seasons (December to February and August to October). Annual average rainfall is $1500 \mathrm{~mm}$. A monthly mean temperature is approximately $27^{\circ} \mathrm{C}$. The warmest month is March and the coolest is August with respectively 28.55 and $25.5^{\circ} \mathrm{C}$. The average annual sunshine lengths are approximately $1790 \mathrm{~h}$. Average relative humidity is $81 \%$. The soil is composed of tertiary sands. Our investigations were conducted from June 2008 to June 2010.

\subsection{Male Inflorescences Entomofauna Study Methods}

To assess the male inflorescences of oil palm insect fauna, three operations were performed: location, sampling and identification of insects. The first operation consisted of taking an inventory of inflorescences in flowering phase. Thus, 50 male inflorescences were recorded. Four spikelets per inflorescence were removed as soon as the third of the flowers of each inventoried inflorescence flowered. This taking away corresponds to the beginning of anthesis (BA). The second sample was taken three days after the first and corresponds to full anthesis (FA). The third collection was done two days after the second and reflects the 
end of anthesis $(E A)$. The taken spikelets were introduced into bags. Insects therein were neutralized using an insecticide bomb. In laboratory, each batch of insects was collected in pillboxes containing alcohol $70^{\circ}$. Identification was made using a binocular microscope and the insect fauna reference collection of oil palm inflorescences of CNRA La Mé.

\subsection{Female Inflorescences Insect Fauna Study Methods}

Adopting N'goran (1982) and Fataye (1984) methods, each month, two non-flowering inflorescences per study plots were located and followed. Three to four days before flowering, using machetes and pruning knife, these inflorescences were cleared from spathes, so leaves were brought out. Each inflorescence was then covered with a muslin sheath attached to the floral stalk. Each evening the bagged inflorescences was controlled in order to follow their evolution per concerned flowering, per hour; all the insects which arrived on the cage were captured using a vacuum cleaner during ten minutes. This operation was conducted from 6 am to $6 \mathrm{pm}$ during the two days of the anthesis length. The collected insects were immediately stored in pillboxes containing alcohol $70^{\circ}$. At the end of the day, the insects collected were sent to laboratory. They were identified using a binocular microscope and the reference insect fauna collection of oil palm inflorescences of CNRA. Insects captured on each plot were identified and counted per species, per inflorescence, per hour and per month.

\subsection{Statistical Analysis}

The averages for each stage of flowering and each species obtained for quantitative study of the insect fauna of male and female inflorescences were calculated using Excel software. A principal component analysis (PCA) and a hierarchical cluster analysis (HCA) were performed using Statistical software version 7.1 to determine underlying information from multivariate raw data.

\section{RESULTS AND DISCUSSION}

\subsection{Entomofauna of Oil Palm Male Inflorescences}

The collected insects on male inflorescences of oil palm tree mostly belong to Elaeidobius (E) genus with 5 species: E. kamerunicus, E. plagiatus (figure 1), E. subvittatus, E. singularis and E. bilineatus (figure 2). Elaeidobuis was followed by Microporum (M) genus represented by $M$. dispar and $M$. congolense (figure 3 ) then by Prosoestus genus that includes $P$. sculptilis and $P$. minor (figure 4). Species Atheta burgeoni, Lithargus sp., Anthocoride sp., Thrips sp., Gabrius sp. and bees (Nomia sp. and Apis mellifera) were also observed. The insect fauna, however, was dominated by $E$. subvittatus with $34 \%, 46 \%$ and $57 \%$ respectively at beginning, full and end anthesis. This first species was seconded by $A$. burgeoni with $47 \%$ at BA, $23 \%$ and $19 \%$ at FA and EA. Except bees, absent at the beginning of flowering; all identified species frequent the inflorescences during all stages of flowering. Generally, the number of insects showed a steady increase which obeys the following order: beginning, end and full anthesis. However the species $P$. minor and E. kamerunicus presented more abundant populations at the beginning than at the end of flowering. All significant correlation coefficients obtained using PCA were positive. These results are confirmed by the different projections of clouds of points in factorial plan ( $1 \times 2$ ) (Figures 5 \& $6)$. 


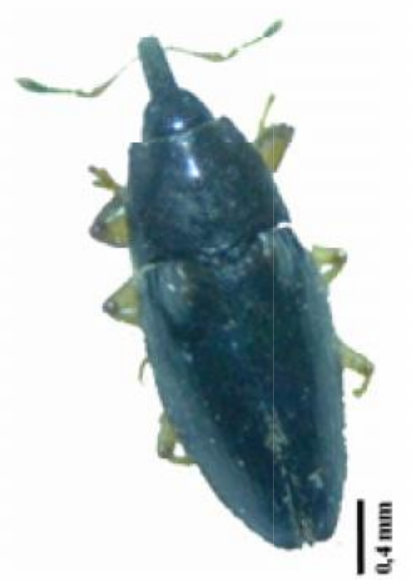

A: Elaeidobius kamertunicus male

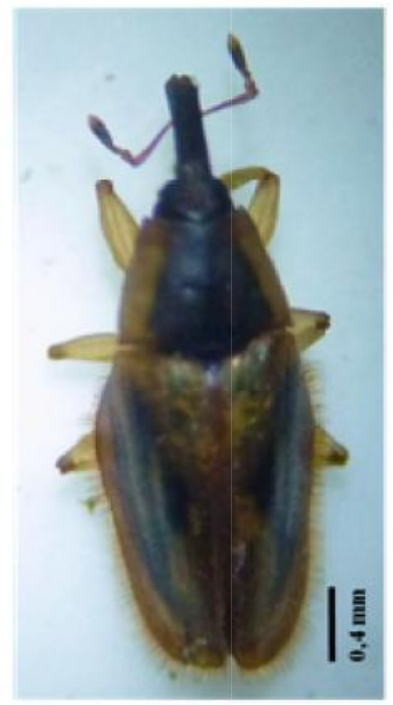

C: Elaeidobius plagiatus male

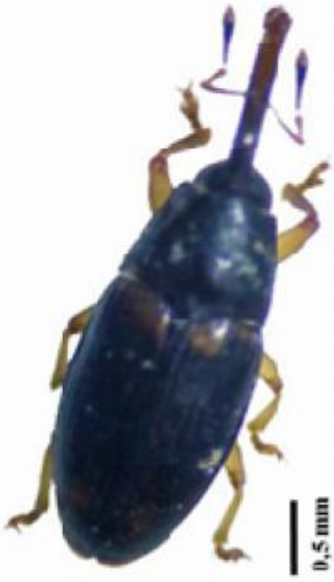

B: Elaeidobius kamerunicus female

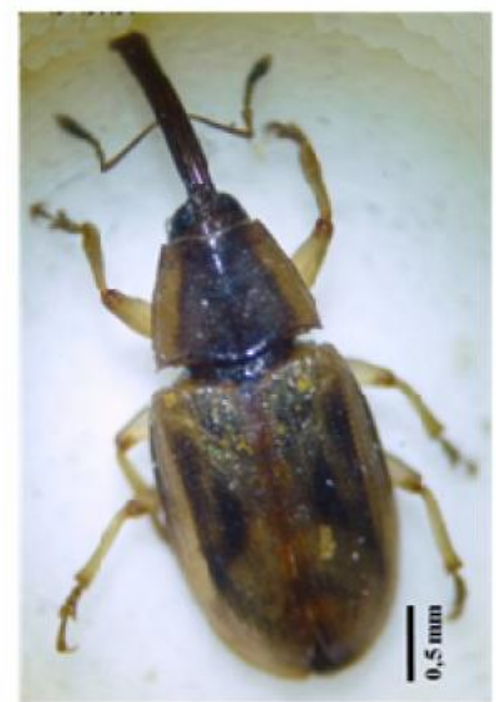

D: Elaeidobius plagiatus female

Fig. 1. Elaeidobius, observed on oil palm tree inflorescence (I) 


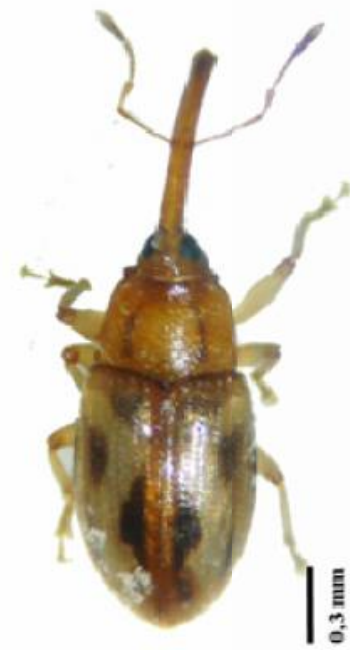

E: Elaeidobius singularis

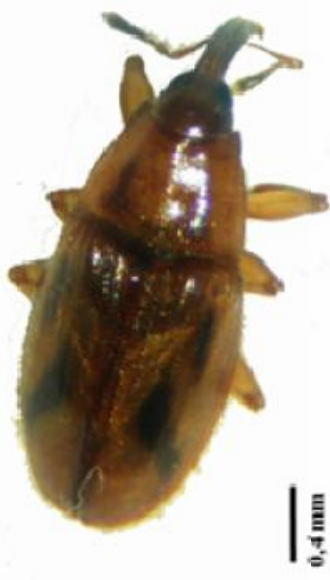

$\mathbf{F}$ : Elaeidobius bilineatus

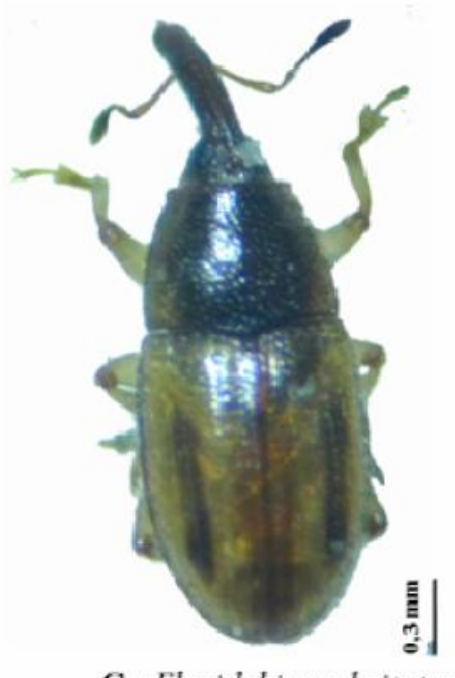

G : Elaeidobius subvitatus

Fig. 2. Elaeidobius, observed on oil palm tree inflorescence (II) 


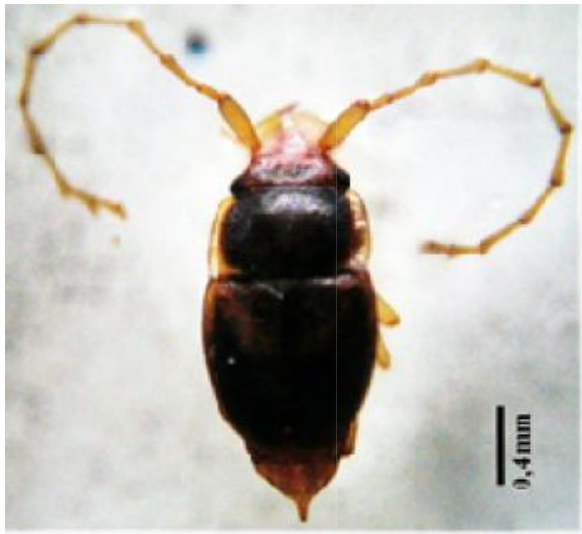

H: Microporum congolense male

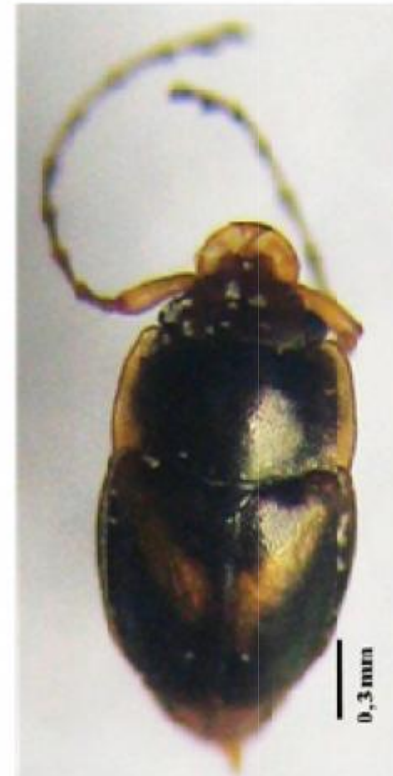

J: Microporum dispar male

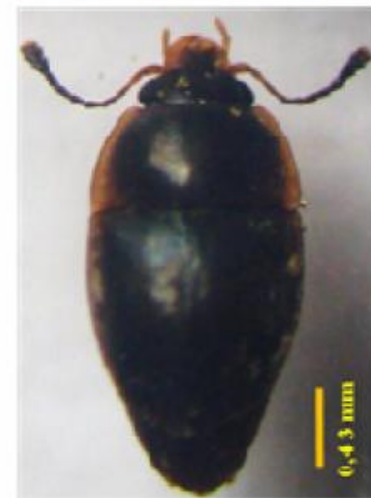

I: Microporum congolense female

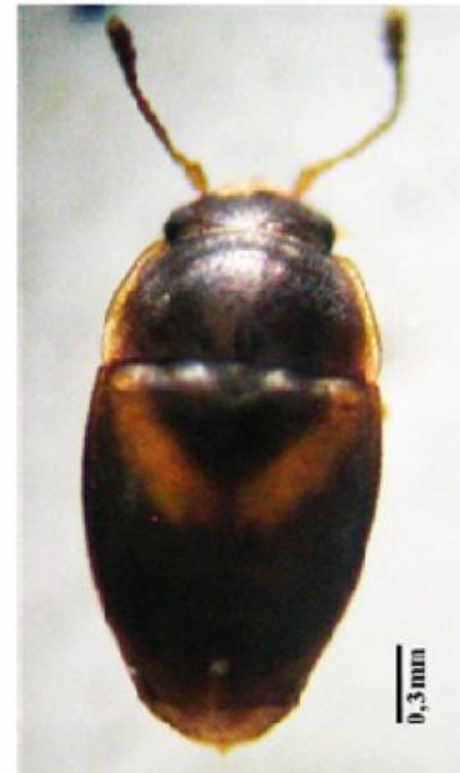

K. Microporim dispar female

Fig. 3. Microporum, observed on oil palm tree inflorescence 
American Journal of Experimental Agriculture, 2(3): 306-319, 2012

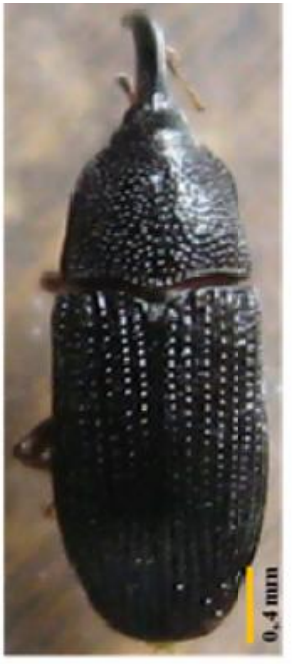

L: Prosoestus minor male

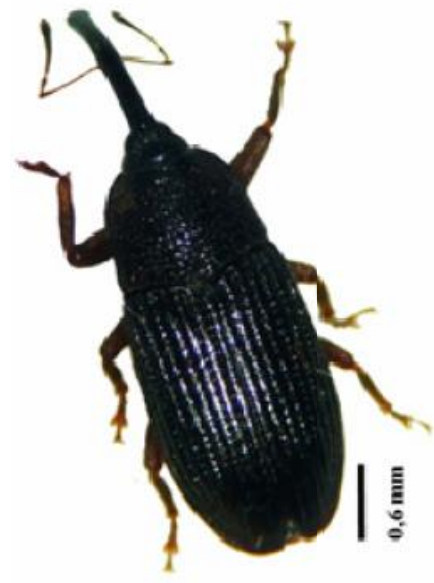

N: Prosoestus sculptilis male

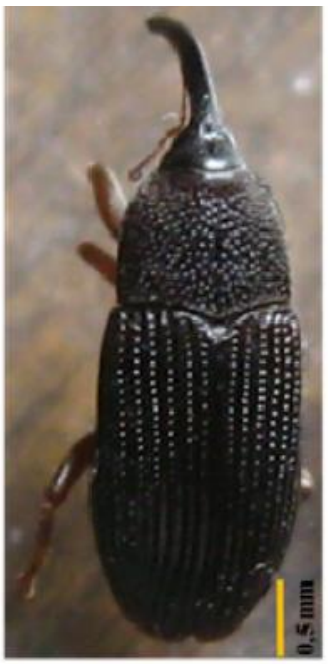

M. Prosoestus minor female

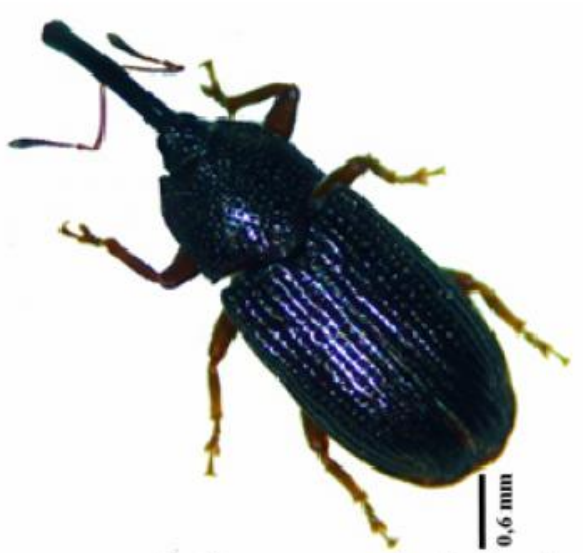

O: Prosoestus sculptilis female

Fig. 4. Prosoetus, observed on oil palm tree inflorescence 

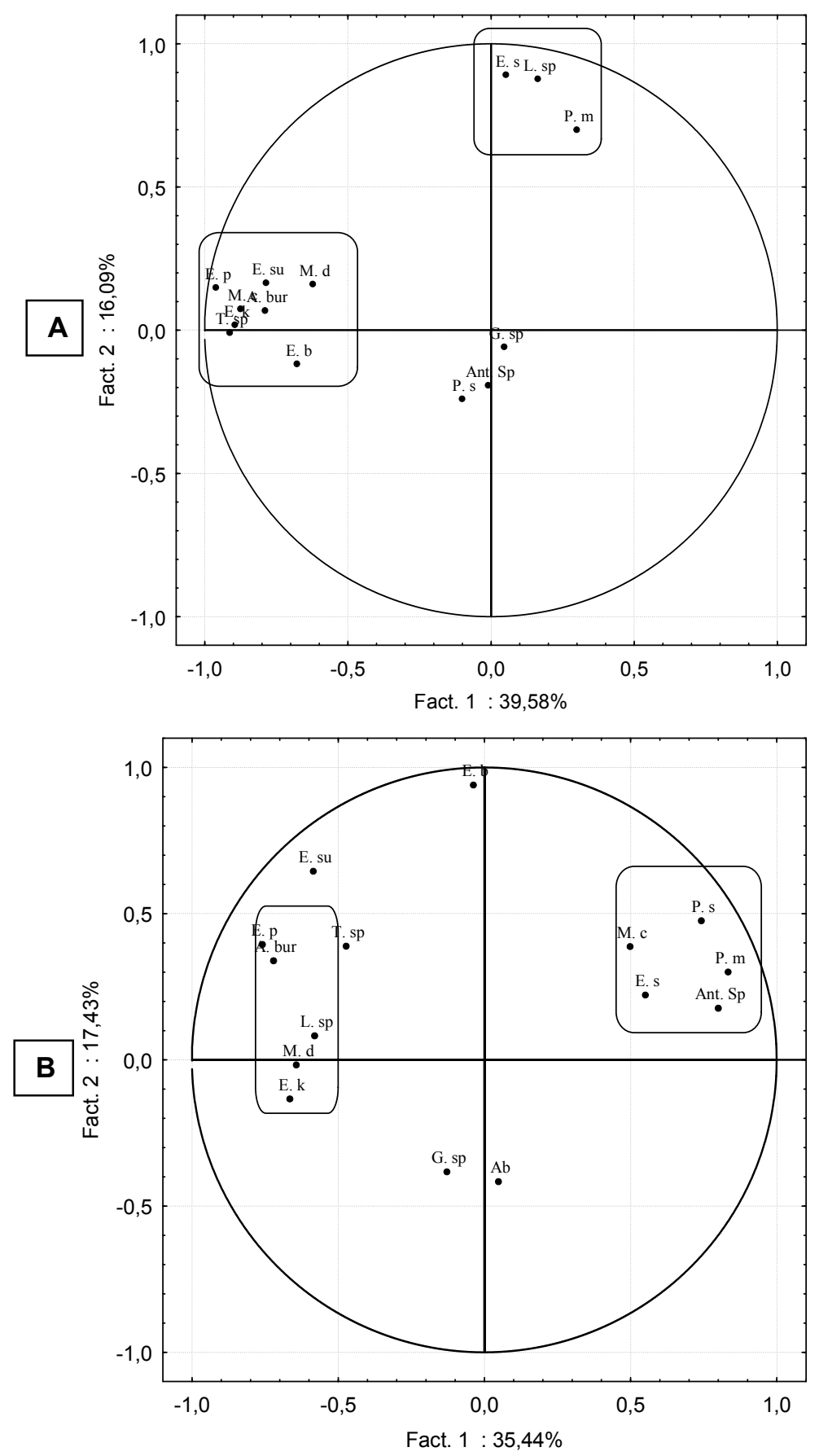

Fig. 5. Principal component analysis of male inflorescences entomofauna A: Beginning anthesis; B: Full anthesis; E. s.: Elaeidobius singularis, L. sp.: Lithargussp; P. m.: Proseostus minor; G. sp.: Gabrius sp.; Ant. sp.: Anthocoride sp.; P. s.: Proseostus sculptilis; E. p.: Elaeidobius plagiatus; E. su.: Elaeidobius subvitatus; M. d.: Microporum dispar; M. c.: Microporum congolensis; A. bur.: Atheta burgeoni; E. k.: Elaeidobius kamerinucus; T. sp.: Thrips sp.; E. b.: Elaeidobius bilineatus. 


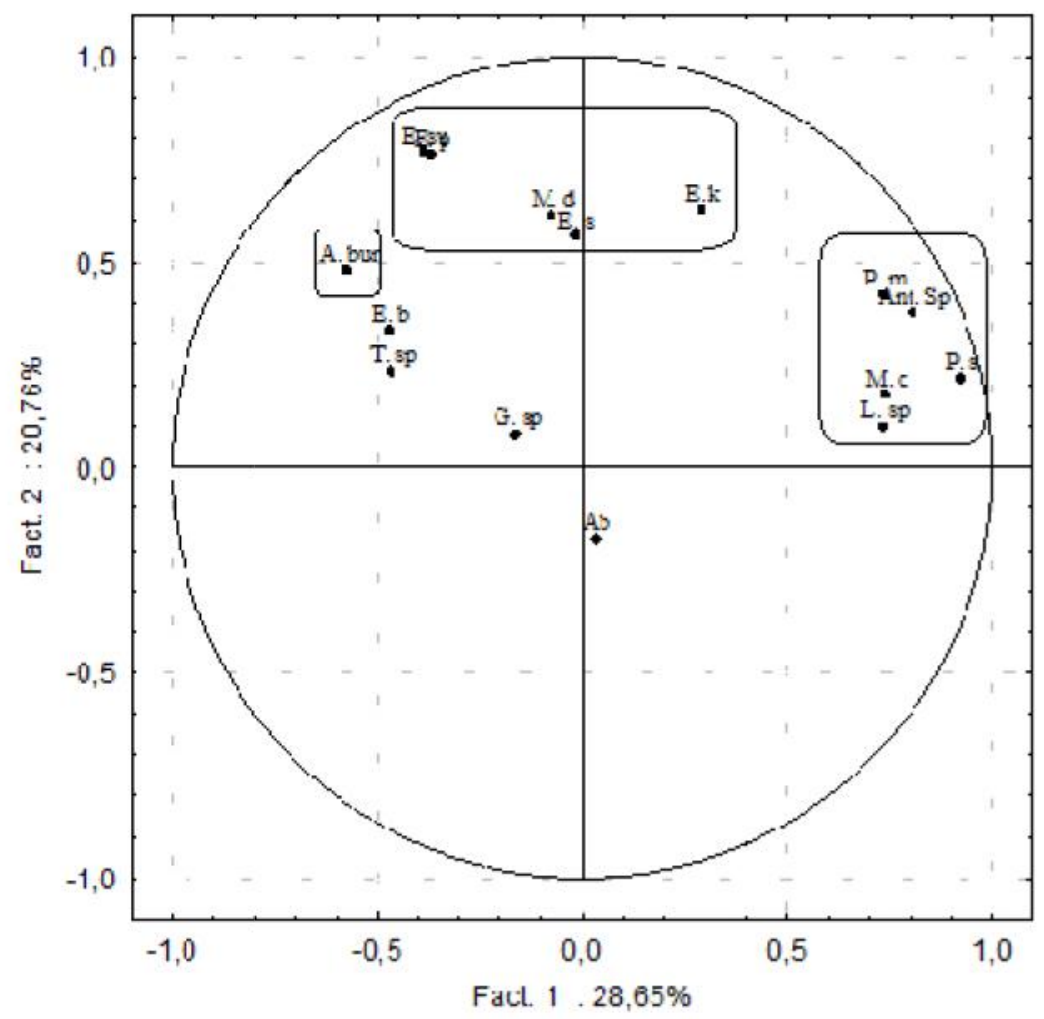

Fig. 6. Principal component analysis of male inflorescences entomofauna at the end of anthesis

E. s.: Elaeidobius singularis, L. sp.: Lithargussp; P. m.: Proseostus minor; G. sp.: Gabrius sp.; Ant. sp.: Anthocoride sp.; P.s: Proseostus sculptilis; E. p: Elaeidobius plagiatus; E. su: Elaeidobius subvitatus; M. d.: Microporum dispar; M. c.: Microporum congolensis; A. bur.: Atheta burgeoni; E. k.: Elaeidobius kamerinucus; T. sp.: Thrips sp.; E. b.: Elaeidobius bilineatus.

Qualitatively, the entomofauna of male inflorescences revealed the following insects: $E$. kamerunicus, E. plagiatus, E. bilineatus, E. subvittatus, E. singularis, M. dispar, $M$. congolense, P. minor, P. sculptilis, Atheta burgeoni, Gabrius sp., Lithargus sp., Thrips sp., Anthocoride sp., Apis sp. and Nomia sp. These results are similar with those obtained in Robert Michaux plantation (Dabou, Côte d'Ivoire) by Desmier De Chenon (1981). They are also similar to those obtained by Mariau et al. (1991) in West Africa at La Mé in Côte d'Ivoire and Aisagbonhi et al. (2004) at Pobé in Benin and at Dibamba in Cameroon. Quantitatively, significant variation was observed from one species to another. These observations were also noted by Mariau and Genty in 1988 and by Mariau et al. (1991). The relative importance of different species would be due to their bio-ecological characteristics. In Malaysia, Thrips $s p$. was very abundant and is the main pollinating agent (Syed, 1982). Before the introduction of Elaeidobius genus, pollinating insects were composed only by Dermoptera, Hymenoptera, Thysanoptera and Diptera (Pouvreau 1984). In South America, Elaeidobius genus was represented only by $E$. subvittatus before the introduction of various species of Elaeidobius (Genty et al., 1986). So, the number of insect varies according to the species and also to the production site. In Côte d'Ivoire, environmental conditions pressed strong support for the growth of three species: Atheta burgeoni, E. subvittatus and E. plagiatus. 
Whatever, the species E. kamerunicusis the main pollinator in Côte d'Ivoire, it is very poorly represented. The results of this study showed that the population of species varies from a stage of flowering to the other. The species were generally more abundant in full flowering excepted $P$. minor and $E$. kamerunicus which presented higher populations in the beginning than at the end of anthesis. The insects are attracted by the anise odor emitted by the flowers at the time of their flowering (Mariau et al., 1991). Thus, the more the number of inflorescences in the flowering phase, the stronger the odor of anise. It is certainly the reason why the level of insects increases as flowering progresses. An affinity has been established between the species E. kamerunicus, E. plagiatus, E. bilineatus, E. subvittatus and $E$. singularis. These species belong to Elaeidobius genus and therefore have certain common characteristics.

\subsection{Female Inflorescences of Oil Palm Insect Fauna}

Outside Thrips sp., bees, Anthocorides sp., Gabrius sp. and Lithargus sp., all species observed on male inflorescences were present on the female inflorescences. It was noted the presence of: Elaeidobius kamerunicus, Elaeidobius plagiatus, Elaeidobius subvittatus, Elaeidobius bilineatus, Elaeidobius singularis, Microporum congolense, Microporum dispar, Prosoestus minor, Prosoestus sculptilis and Atheta burgeoni. These species were present as well the first day as the second day of flowering. However their activity was more important on the first day than the second. Thus during the first day, the ratio of collected insect represented $74 \%$ of the total population. This proportion fell to only $26 \%$ in the second day. Activity was most intense between $9 \mathrm{am}$ and $1 \mathrm{pm}$ with a peak at $11 \mathrm{am}$ (Figure 7). On a total of 30, 067 insects, 12, 499 or $41.57 \%$ were E. subvittatus. This species was followed by the species $E$. kamerunicus, P. minor, E. singularis, E. plagiatus, P. sculptilis, M. dispar, $M$. congolense, $A$. burgeoni and $E$. bilineatus, with respectively: $18.14 \%, 15.13 \%, 10.77 \%$, $5.02 \%, 3.39 \%, 2.24 \%, 1.84 \%, 1.54 \%, 0.36 \%$ (Figure 8). No relation of competition could be established between the species on the female inflorescences. Indeed, all significant correlation coefficients were positive. These tests were confirmed by the projection of the scatter in the factorial plan (1 x 2) (Figure 9).

The entomofauna of the female inflorescences showed qualitatively that all species collected on male inflorescences were not all present on these inflorescences. The species of Elaeidobius, Atheta, Microporum and Prosoestus genus were also identified. Mariau et al. (1991) reported that species of Elaeidobius and Microporum genus were generally attracted by both male and female inflorescences of oil palm tree during flowering. Mariau and Genty (1988) noted that Staphylinidae Atheta sp. was also present in male and female inflorescences. Regarding the species of Prosoestus genus, their presence was announced firstly by Philippe (1993). According to his study, Prosoestus minor and P. sculptilis cause many damage to stigmas and gynoecium of flowers. Among the species collected on the male inflorescences, only Prosoestus realize their life cycle on the female inflorescences. Pouvreau (1984) reported that in West Africa, $14.2 \%$ of the pollinating fauna of a male inflorescence can visit female inflorescences against $16.3 \%$ in the opposite case. Insects' attraction for inflorescences depends highly also of species and characteristics of flowers. According to Pouvreau (1984), although the smell of anise is attractive, sugar concentration of the liquid coating the surface of stigma was not enough to attract the insects of Apidae families. The insects of this family prefer the flowers whose nectar sugar concentration is relatively high (Corbet, 1997). That's certainly why some bees attend the inflorescences of oil palm. 


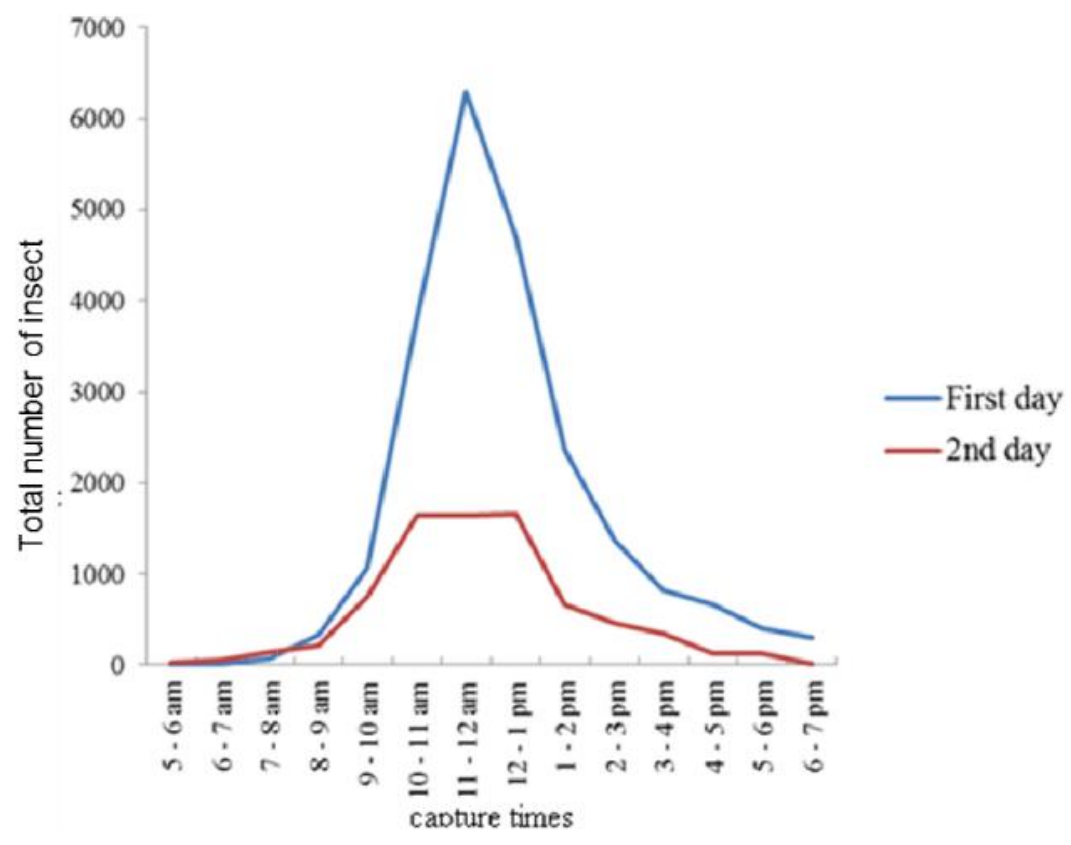

Fig. 7. Variation of activity of insects on female inflorescences during anthesis

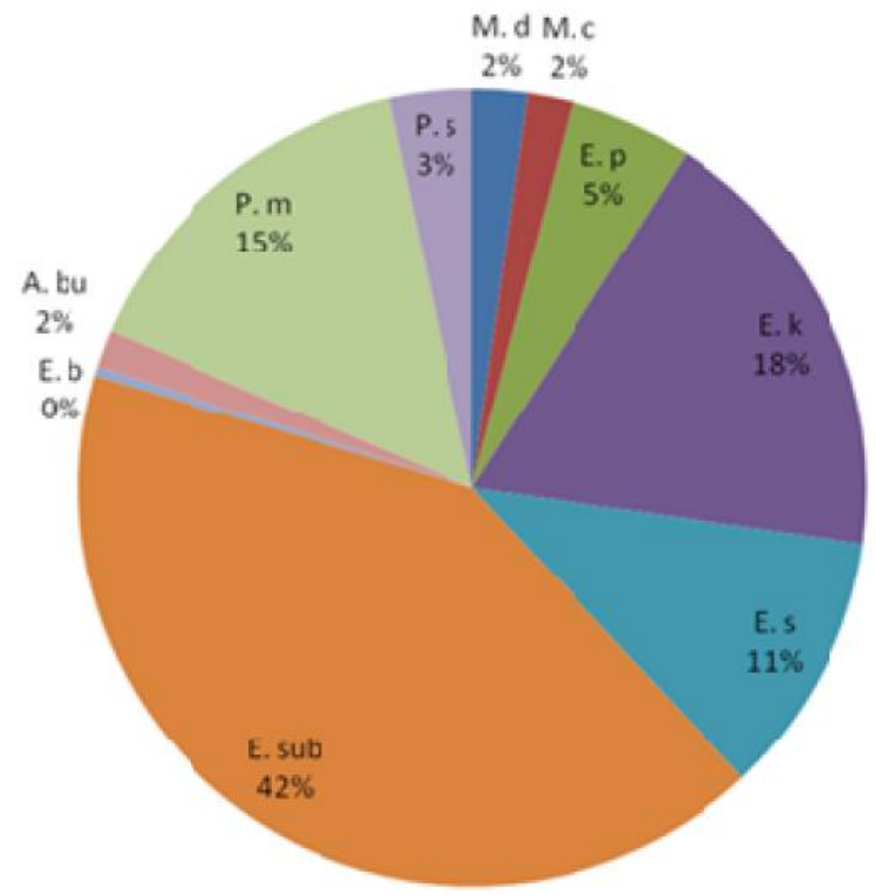

Fig. 8. Distribution of insect species on the male and female inflorescences

E. sub.: Elaeidobius subvitatus, E. s.: Elaeidobius singularis, E. k.: Elaeidobius kamerinucus, E. p.: Elaeidobius plagiatus, M. c.: Microporum congolensis, M. d.: Microporum dispar, P. s.: Proseostus sculptilis, P. m.: Proseostus minor, A. bu.: Atheta burgeoni, E. b.: Elaeidobius bilineatus. 

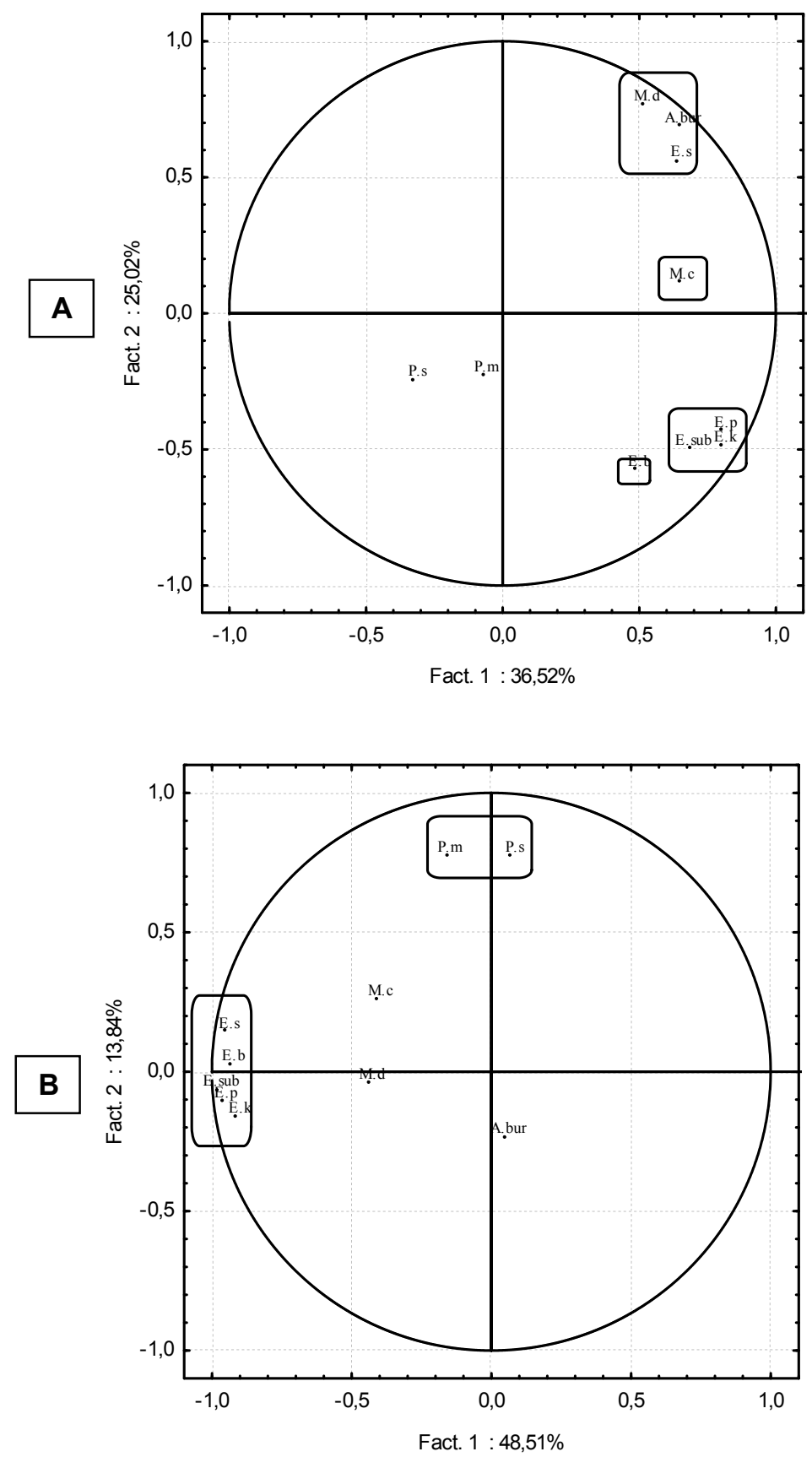

Fig. 9. Principal component analysis of female inflorescences entomofauna. (A: first day; $B$ : second day)

E. s.: Elaeidobius singularis; L. sp.: Lithargus sp.; P m.: Proseostus minor; G. sp.: Gabrius sp; Ant. sp: Anthocoride sp.; P. s.: Proseostus sculptilis; E. p.: Elaeidobius plagiatus; E. su.: Elaeidobius subvitatus; M. d.: Microporum dispar; M. c.: Microporum congolensis; A. bur.: Atheta burgeoni; E. k.: Elaeidobius kamerinucus; T. sp.: Thrips sp.; E. b.: Elaeidobius bilineatus. 
Quantitatively, this study has shown that the species of Elaeidobius genus and especially $E$. subvittatus were most numerous. Mariau et al. (1991) reported that insects present on female inflorescences were extremely variable. According to these authors, E. subvittatus represents for $54 \%$ of the total insect collected, E. plagiatus and E. kamerunicus (20\%) and $E$. singularis $(6 \%)$. The high activity of $E$. subvittatus could be linked to its important presence on the male inflorescences. The higher level of insects' activity was observed between $9 \mathrm{am}$ and $1 \mathrm{pm}$ with a peak at 11 am during the two successive days of flowering. During this period, flowers probably release the highest quantity of nectar sought by the insects. The time in a day corresponding to a maximum secretion of nectar varies according to plant species: in the morning for Citrus limon, after midday for Tropaelum majus, in the night for Capparis spinosa (Pouvreau, 1984). The population of insects is more important the first day of flowering than the second. This is certainly due to the fact that flowers bloom mostly on the first day.

\section{CONCLUSION}

The insect fauna of inflorescences of oil palm tree has not changed qualitatively since the last census. E. subvittatus was the most abundant species at all stages of flowering. No competition relationships have been established between different species of insects captured. Insect species present on the two types of inflorescences are potential pollinators. A study of the ability of pollinating insects is necessary for a better management of pollination of oil palm tree.

\section{ACKNOWLEDGEMENTS}

The authors gratefully acknowledge financial support and the provision of facilities from the National Center of Agronomic Research of Côte d'Ivoire (West Africa).

\section{COMPETING INTERESTS}

Authors have declared that no competing interests exist.

\section{REFERENCES}

Aisagbonhi, C.I., Kamarudin, N., Aokwuagwu, M., Mohd, B.W., Jacson, T., Adaigbe, V. (2004). Preliminary observations on a field population of the oil palm-pollinating weevil Elaeidobius kamerunicus in Benin City, Nigeria. Int. J. of Trop. Ins. Sci., 24(3), 255-259.

Anonyme. (2009). Bulletin d'information du fond interprofessionnel pour la recherche et leconseil agricole, Acte 5.55 p.

Boutin, D. (2007). Le palmier à huile. CIRAD $29 \mathrm{p}$.

Chevalier, A. (1910). Les végétaux utiles de l'Afrique tropicale française, fasc. 7 (1ère partie) - Paris, $127 \mathrm{p}$.

Corbet, S.A. (1997). Role of pollinators in species preservation, conservation, ecosystem stability and genetic diversity. Acta Hort., 437, 219-228.

Desmier De Chenon, R. (1981). Entomophile pollination of oil palm in West Africa. Preliminary research. In: The oil palm in agriculture in the eighties. Incorporated Society of Planters ed. Malaysia, 1, 239-291. 
Fataye, A. (1984). Rôle des principaux insectes dans la pollinisation des palmiers à huile en Côte d'Ivoire. Rapport de stage de fin de première année agronomique, ENSA, AbidjanStation palmier à huile IRHO-CIRAD de La Mé, Cl, $26 \mathrm{p}$.

Genty, P., Garzon, A., Lucchin, F., Delvare, G. (1986). Pollinizacion entomofila de la palma africana en America tropical. Oléagineux, 41(3), 99-112.

Mariau, D., Genty, P. (1988). Contribution de l'IRHO à l'étude des insectes pollinisateurs dupalmier à huile en Afrique, Amérique du sud et Indonésie. Oléagineux, 43(6), 233237.

Mariau, D., Houssou, M., Lecoustre, R., Ndigui, B. (1991). Insectes pollinisateurs du palmier à huile et taux de nouaison en Afrique de l'ouest; Oleagineux, 46(2), 43-49.

N'Goran, D.F. (1982). Etude du trafic des insectes sur les fleurs femelles des palmiers à huile; importance des populations sur les fleurs mâles. Rapport de stage de fin de première année agronomique, ENSA, Abidjan- Station palmier à huile IRHO-CIRAD de La Mé, Cl.13 p.

Pene, C.B., Assa, D.A. (2003). Variations interannuelles de la pluviométrie et de l'alimentation hydrique de la canne à sucre en Côte d'Ivoire. Sécheresse, 14, 43-52.

Pouvreau, A. (1984). Cultures tropicales oléagineuses in Pollinisation et production végétale (coordonné par PESSON P., LOUVEAUX J.), INRA, Paris. 331- 347.

Philippe, R. (1993). Etude de l'incidence des ravageurs sur les inflorescences femelles du palmier à huile en Afrique de l'Ouest. Oléagineux, 48(10), 389-405.

Seyd, R.A. (1979). Studies on oil palm pollination by insects. Bull. Ent. 319 Res., 69, 213224.

Seyd, R.A., Law, I.H., Corley, R.H.V. (1982). Insect pollination of oil palm: introducing, establishment and pollinating efficiency of E. kamerunicus FRAUSTY in Malaysia. Incorporated Society of Planters, ed. Vol. 58, p. 547-560.

Traoré, K., Mangara, A., (2009). Etude Phyto-écologique des Adventices dans les Agroécosystèmes élaeicoles de la Mé et de Dabou. Eur. J. Sci. Res., 65, 519-533.

Seyd, R.A. (1979). Studies on oil palm pollination by insects. Bull. Ent. Res., 69, 213-224.

Seyd, R.A, Law, I.H., Corley R.H.V. (1982). Insect pollination of oil palm: introducing, establishment and pollinating efficiency of E. kamerunicus FRAUSTY in Malaysia. Incorporated Society of Planters ed. Vol. 58, p. 547-560.

Traoré, K., Mangara, A., (2009). Etude Phyto-écologique des Adventices dans les Agroécosystèmesélaeicoles de la Mé et de Dabou. Eur. J. Sci. Res., 65, 519-533.

(C) 2012 Hala et al.; This is an Open Access article distributed under the terms of the Creative Commons Attribution License (http://creativecommons.org/licenses/by/3.0), which permits unrestricted use, distribution, and reproduction in any medium, provided the original work is properly cited. 